CIRR XXII (76) 2016, 5-28

ISSN 1848-5782

UDC 3/4.742:33 1.5/497.5:439:497.4)

DOI 10.1515/cirr-2016-0004

\title{
Attitudes Towards Immigrants, Immigration Policies and Labour Market Outcomes: Comparing Croatia with Hungary and Slovenia
}

Valerija Botrić

\section{Abstract}

The paper provides comparative evidence on attitudes towards immigrants, their labour market outcomes and policies in Croatia and two neighbouring countries - Slovenia and Hungary. Three different data sources have been used: the European Social Survey, an ad-hoc Labour Force Survey module for the year 2014, and the MIPEX index. Although immigrants have a disadvantaged position on the Croatian labour market, most analysed indicators do not imply that they are in a worse position than in other European economies. Migrant integration policies related to the labour market are assessed as being relatively favourable for Croatia. Judging by the comparable indicators for the native population in Croatia, immigrants' adverse labour market outcomes seem to be more related to the unfavourable general economic situation, and particularly by the deep and long recession.

KEY WORDS:

immigration, labour market outcomes, comparative analysis, Croatia 
Recent migration flows have raised many issues in European economies and societies. Although public discussions are more likely to reach consensus when the need to address the humanitarian aspects of the migrant crisis are considered, more dissonant tones soon prevail when the economic issues in terms of who is responsible for bearing the costs come into focus. The increased inflow of migrants has been, from the very beginning, viewed from the aspect of the migrants providing the additional necessary workforce required to fill the gaps occurring on the domestic labour market due to the demographic aging processes affecting the wider European area. The length of the migrant crisis has led to questions concerning the pressures on the fiscal sustainability of social benefits schemes, the willingness of migrants to seek jobs, the availability of specific labour market demand to accommodate the additional labour supply. Within this recent migration crisis, Croatia has been a transitory country, with only a small number of immigrants seeking asylum. However, this might change in the near future due to a number of reasons, influenced by internal or external factors. One reason might be related to the joint agreement reached by the European Union members on the adoption of a quota system, regardless of the likelihood of reaching such a political agreement to account for all the arriving migrants. The other reason might be the adoption of a more active immigration policy design, motivated by demographic aging of Croatian society (Nejašmić and Toskić 2013). Finally, Croatia has been, prior to recent economic crisis, a country with a mixed record regarding net migration flows (Akrap 2014). This could mean that once the effects of the economic crisis have been overcome, the Croatian economy might again be attractive for immigrants from less developed countries.

In order to provide more perspective on the relative position of Croatia with respect to the discussion of the consequences of the recent migration crisis, this paper compares three aspects - attitudes towards immigrants, the labour market outcomes of immigrants, and policy integration measures - in Croatia with those in two neighbouring countries also affected by the recent transitory migration flows - Slovenia and Hungary. The expected contribution of such an overview can be found in the ways in which an increased awareness of the present situation can enable the anticipation of 
future issues and contribute to the discussion concerning the policies aimed at improving the economic integration of immigrants, acknowledging that this is only one segment of the overall integration process of immigrants. The choice of these specific aspects was guided by the previous findings in the literature. Attitudes towards immigrants are related both to the policies adopted and to labour market outcomes, and there is an assumption that there is a correlation between the policies adopted and the labour market outcomes. However, the comparative approach taken in this paper has not been previously explored in the Croatian literature.

The aim of the paper is to provide a specific comparative overview, relying on comparable data sources. The attitudes towards immigrants have been explored by utilizing European Social Survey (ESS) data. In order to analyse labour market effects, recently released Eurostat data from an ad-hoc module of the Labour Force Survey (LFS) has been used in order to ensure methodologically consistent indicators are used across the analysed countries. Since this is the first time a migration ad-hoc module has been carried out in the Croatian LFS, the data provide a unique opportunity to put national indicators in a wider European perspective. Finally, a comparison of the policy mixes aimed at the integration of immigrants in Croatia, Hungary and Slovenia have been analysed using the Migrant Integration Policy Index (MIPEX).

The structure of the paper is as follows: The next section briefly provides some context, section 3 presents a comparative analysis of attitudes towards immigrants in the three countries, section 4 discusses key policy challenges, while Section 5 discusses the labour market outcomes of immigrants. The last section provides a summary and a roadmap for future analysis.

\section{General context: recent data and findings from the literature}

The migration crisis began in 2011 with the onset of the Arab Spring, but strongly affected the analysed countries in 2015 . Prior to the outburst of 
migration flows, the three analysed countries had relatively low migration flows, as documented by the data in Table 1. The data clearly shows that all the analysed countries recorded negative net migration flows in recent years, among which the number for Croatia' is the largest. Also, it should be noted that migration flows intensified in the cases of Hungary and Croatia, while no such trends were recorded in Slovenia.

Table 1. Migration flows in Croatia, Hungary and Slovenia

\begin{tabular}{|l|l|l|l|l|l|}
\hline & $\mathbf{2 0 1 0}$ & $\mathbf{2 0 1 1}$ & $\mathbf{2 0 1 2}$ & $\mathbf{2 0 1 3}$ & $\mathbf{2 0 1 4}$ \\
\hline HR_immigration & 4985 & 8534 & 8959 & 10378 & 10638 \\
\hline HR_emigration & 9860 & 12699 & 12877 & 15262 & 20858 \\
\hline Net & -4875 & -4165 & -3918 & -4884 & -10220 \\
\hline HU_immigration & 1635 & 5504 & 13362 & 17718 & 28577 \\
\hline HU_emigration & 7318 & 12413 & 12964 & 21580 & 31385 \\
\hline Net & -5683 & -6909 & 398 & -3862 & -2808 \\
\hline SI_immigration & 15416 & 14083 & 15022 & 13871 & 13846 \\
\hline SI_emigration & 15937 & 12024 & 14378 & 13384 & 14336 \\
\hline Net & -521 & 2059 & 644 & 487 & -490 \\
\hline
\end{tabular}

Source: national statistical offices.

Bearing in mind these numbers, it can already be assumed that dealing with the large migration flows that passed through the territories of these countries along the so-called Balkan route ${ }^{2}$ created increased logistical pressures, and raised questions concerning whether the economies and societies of these countries would be able to cope with these issues. The rest of the paper is devoted to discussing some of the issues related to the ability of these countries to absorb more immigrants, with special focus on Croatia.

Notwithstanding the recent large migration flows, the extant studies have revealed that migration is not a novel phenomenon (Borjas 2003; Smith and Fernandez 2015; Ortega and Peri 2013; Lewis 2011; Kleven et al. 2014; Hatton 2015). For example, if we concentrate on the 2000-2010 period, 70 per cent of the increase in the labour force in Europe and 15 per cent of the entries into the rapidly growing occupations in Europe can be

1 The latest census data for Croatia (for the year 2011) reveals that 44.8 per cent of immigrants originate from Bosnia and Herzegovina. Botrić (2015) also discusses the contribution of migration flows from the Western Balkan countries to Croatia's recent net migration position.

2 Frontex estimates more than 764,000 individuals took the Balkan route during 2015. Available at: http://frontex.europa. eu/trends-and-routes/western-balkan-route/ 
attributed to immigrants (OECD/European Union 2014). The immigration issues that recently became the focus of public discussion have long been the subject of scientific curiosity. The basic questions in the literature are why people migrate and what the consequences of migration are.

Certainly, economic factors play an important role when immigrants chose their destination country (Borjas 1987). One of the most evident push factors is the desire to ensure for themselves and their families better overall living conditions, which can be achieved in politically stable environments with a prosperous economy. As with all other social activities, individuals' perceptions (however they might be formed) are important in making the decision. In addition to personal security, the possibility to find a job (i.e. relatively low unemployment rates in the destination country and a less restricted labour market) certainly provides motivation. Consequently, labour market conditions relatively quickly come into focus when individuals make their decision to migrate.

Regarding the impact on the host country, the public focus is currently focused on the costs of increased immigration flows (Facchini and Mayda 2009). Some studies go even further and suggest that immigrants are sometimes blamed for various problems in society, such as the unemployment of the native population (Schieve and Slaughter 2001). Marino et al. (2015) propose that immigrants could be viewed as outsiders, in the classic insider-outsider labour market relationship where insiders protect their position to the disadvantage of the outsiders. In the same direction, Krings (2009) documents that unions frequently campaign against immigration, as in their view this increased supply-side competition will increase the bargaining power of employers and undermine employees' rights. Within that context, some authors argue that anti-immigration campaigns originate in the fear of social dumping (Meardi 2012).

In studying the effects of immigrant on local economies' labour markets, it is important to distinguish between the quantity (jobs) and price (wages) effect. In a closed economy model with a high rate of substitution between immigrants and natives (due to similar a structure in education, age, and available skills), increased immigration can reduce the demand for native labour. However, if the elasticity of substitution is low, then the effects of additional labour supply are negligible (Ottaviano and Peri 2012). In the 
latter case, labour markets might not be affected by immigration, but this does not imply that the system of social security will not be additionally burdened in cases when immigrants will not be able to find a suitable job. Considerations related to job competition and social benefits severely affect the attitudes of the general population towards immigrants.

Open economy standard models rely on Heckscher-Ohlin trade effects that act to balance the increased labour supply. Leamer and Levinsohn (1995) argue that the wages of local workers will not be affected by additional immigration, due to the "factor price insensitivity". However, in order for this result to hold all factors of production (including labour) need to be mobile between different industries - an assumption that has been frequently refuted when confronted with evidence.

The studies on European economies usually find that immigrants have lower labour force participation, higher rates of unemployment, and are frequently clustered in lower-paid jobs (Heath et al. 2008). Although it could be argued that part of the adverse outcomes could be attributed to the different structure of immigrants in comparison to the native population (in terms of education, age, skills, language proficiency, etc.), empirical studies find that even after accounting for such factors, the adverse position of immigrants in local labour markets remain (Carmichael and Woods 2000; Kahanec et al. 2010; Reyneri and Fullin 2011).

The importance of the immigration issue for the future of the European Union (EU) has recently been emphasized by Toshkov and Kortenska (2015). Their empirical analysis suggests that the level of immigration from new EU member states is negatively associated with the support for European integration in the host countries. Markaki and Longhi (2013) provide evidence that regions with a higher proportion of (non-EU) immigrants and with higher unemployment among the immigrants more frequently exhibit anti-immigrant attitudes (regardless of the depth of the unemployment problems facing the native population). So, even though the idea of the European Union rests on the free movement of labour in order to alleviate regional economic disparities and enable the absorption of asymmetric shocks within the Union, the political reality might be leading to the development of an internal paradox. An illustration of the recent failure to 
The European Union studies seldom include considerations of the Croatian economy, while Croatian studies usually focus only on domestic issues. Thus, in the next sections, a comparative approach has been taken to provide a bridge between these two strains of the literature.

\section{Attitudes towards immigrants: comparing Croatia, Hungary and Slovenia}

Attitudes towards immigrants are diverse across societies, a finding generally explained by two groups of theories - individual and collective (Rustenbach 2010). The first emphasizes education differences, personal income, the employment status of immigrants, as well as specific cultural differences as the main reasons behind adverse attitudes towards immigrants. The collective theories explore aggregated variables - such as the share of the immigrant population in total or the level (and trend) of the unemployment rate in a country. Both strains of the literature thus emphasize economic (in particular labour market) predictors of attitudes.

Previous research on attitudes towards immigrants in Croatia has established that when it comes to foreign workers, negative responses prevail (Čačić-Kumpes et al. 2012). Although some studies emphasize the combination of economic, cultural, and security threats that shape overall attitudes towards immigrants (Franc et al. 2010), others focus on ethnocentrism (Šram 2010) and its causes. Recently, Gregurović et al. (2016) focused specifically on the eastern part of Croatia and emphasized the relationship between conservatism and negative attitudes towards immigrants. The overall conclusion from these studies is that there is a certain degree of negative attitudes towards the immigrant population, nurtured within specific segments of the society.

However, in order to provide a comparative perspective on Croatia, the data has to encompass other economies as well. To that end we rely 
on the European Social Survey 3 (ESS). The key questions analysed in this paper are the following:

- IM_same_race: to what extent do you think [country] should allow people of the same race or ethnic group as most [country] people to come and live here? Scale ranging from 1 (allow none) - 4 (allow many to come)

- IM_diff_race: How about people of a different race or ethnic group from most [country] people? Scale ranging from 1 (allow none) - 4 (allow many to come)

- IM_poor: How about people from the poorer countries outside Europe? Scale ranging from 1 (allow none) - 4 (allow many to come)

- IM_economy: Would you say it is generally bad or good for [country]'s economy that people come to live here from other countries? Scale ranging from 0 (bad for the economy) - 10 (good for the economy)

- IM_culture: And, using this card, would you say that [country]'s cultural life is generally undermined or enriched by people coming to live here from other countries? Scale ranging from 0 (cultural life undermined) - 10 (cultural life enriched)

- IM_impact: Is [country] made a worse or a better place to live by people coming to live here from other countries? Scale ranging from 0 (worse place to live) - 10 (better place to live)

The average score for each country can be interpreted as an indicator of relative revealed preferences of Croatian, Hungarian, and Slovenian population. Although the data for Hungary and Slovenia are disclosed for all ESS rounds, the latest data for Croatia is available for ESS round 5, referring to the year 2010 . The results are presented in the following figure. ${ }^{4}$

3 The European Social Survey is cross-national survey providing comparative data on individuals' attitudes, beliefs, and behaviour patterns. Up until now, seven rounds of the Survey have been conducted biannually, starting in the year 2002. The questionnaire has evolved from the first Survey, but careful documentation of the methodology, including sampling and individual data is available to interested reader on http://www.europeansocialsurvey.org/about/. So far, the results have been widely used by the academic community, as documented by the ESS bibliography of papers using this rich dataset. Available at: http://www.europeansocialsurvey.org/bibliography/

4 Post-stratification weights have been applied to obtain the results. The countries included in round 5 were: Belgium, Bulgaria, Croatia, Cyprus, Czech Republic, Denmark, Estonia, Finland, France, Germany, Greece, Hungary, Ireland, Israel, Lithuania, Netherlands, Norway, Poland, Portugal, Russian Federation, Slovakia, Slovenia, Spain, Sweden, Switzerland, Ukraine, and the United Kingdom. 
Figure 1. Indicators of attitudes towards immigrants in Croatia, Hungary, and Slovenia

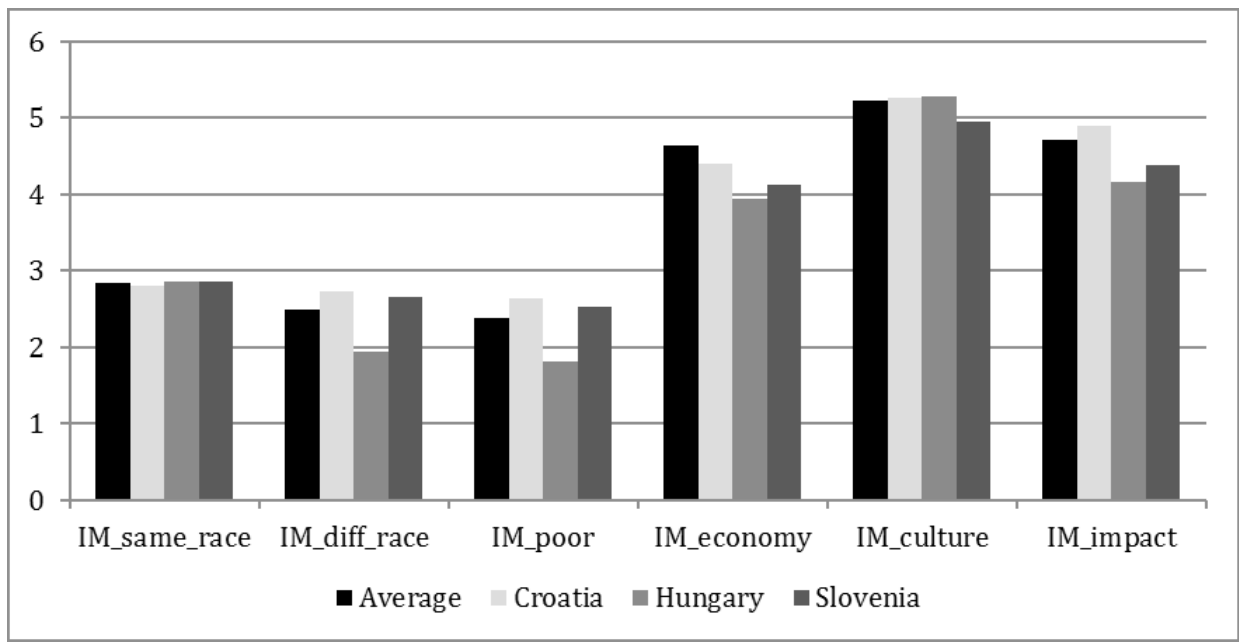

Source: ESS round 5 (http://www.europeansocialsurvey.org/).

Notes: IM_* labels are explained in the text in more detail.

The data reveal that the answers to the first question, which considers immigrants of the same race or ethnic group, seem to be the most homogenous. The second question refers to attitudes towards immigrants of a different race or ethnic group and here it seems that Hungary is less open, while Slovenia and Croatia seem to be more open towards immigrants with these characteristics. A similar situation is found when we consider immigrants originating from less developed economies outside Europe.

When considering the perceived impact of immigrants on the economy of the host country, respondents in all three analysed countries expect a less than average positive impact, with Hungary being the most pessimistic. They are slightly more than average optimistic regarding enriching the cultural life in Croatia and Hungary, and slightly less optimistic in Slovenia. Finally, Croatian respondents believe that Croatia was improved by previous immigrants, while Slovenian and Hungarian respondents report less than average conviction that their countries experience benefits from previous migration flows.

It is important to notice that all of these preferences depict the situation prior to the latest migration crisis in Europe, since they refer to the year 2010. Also, many European countries have since more or less successfully 
weathered the recent economic crisis, and the perceived fiscal burden might not be crucial in forming the average opinion. We can speculate whether more recent data will reflect the increase of adverse attitudes towards immigrants, as indicated in the public debates and political actions (Lucassen and Lubbers 2012) in some European economies. However, whether the average score will have dramatically changed or whether this issue will deepen the polarisation within the societies, is left for future analysis once the data becomes available.

\section{Migration policy challenges}

This section is focused on the comparative analysis of the policies in the three analysed countries, in the period prior to the outbreak of the migration crisis. Even within the European Union, which relies on the pillar of free movement of people, the countries define their own policies when it comes to migration. This generates a need to assess the policy stances in different countries in a comparable way. The latest assessment of migration policies is available for the year 2014, based on MIPEX methodology. ${ }^{5}$ Although the overall integration policy assessment for Croatia is not favourable, ${ }^{6}$ the assessment of the labour market segment (with the score of 54, which reads "halfway favourable") is not the weakest link in the overall policy mix. The data in Figure 2 shows that Croatia's neighbouring countries do not, in general, fare better than Croatia when it comes to the assessment of labour market policies. However, this does not imply that labour markets are able to accommodate the increased number of participants arriving through migration. Even though the policy instruments are developed, the overall economic situation in Croatia is still not favourable for increased job creation. Similarly to many other transition economies, Croatia has experienced a phase of "jobless

5 The Migrant Integration Policy Index (MIPEX) relies on 167 policy indicators and (for the analysed year) covers 38 countries. The indicators are used to analyse eight policy areas of integration: labour market mobility, education of children, political participation, family reunion, access to nationality, health, permanent residence, and antidiscrimination. The indicators are combined to create an aggregated indicator ranging from 0-100, the higher the indicator the more the integration policy mix is favourable towards immigrants. Please refer to Huddleston et al. (2015) for more details on methodology. Available at: http://www.mipex.eu/.

6 Among the analysed countries, Croatia has the lowest overall score (44) followed by Hungary (46) and Slovenia (48). The highest score has been achieved by Sweden (78), while Turkey (25) was assessed as having the least favourable integration policies towards immigrants. 
growth" (Zaiceva 2014; Richter and Witkowski 2014). Whether in the postcrisis period a positive growth-employment relationship will be established still remains to be seen.

Figure 2. MIPEX scores - labour market mobility, 2014

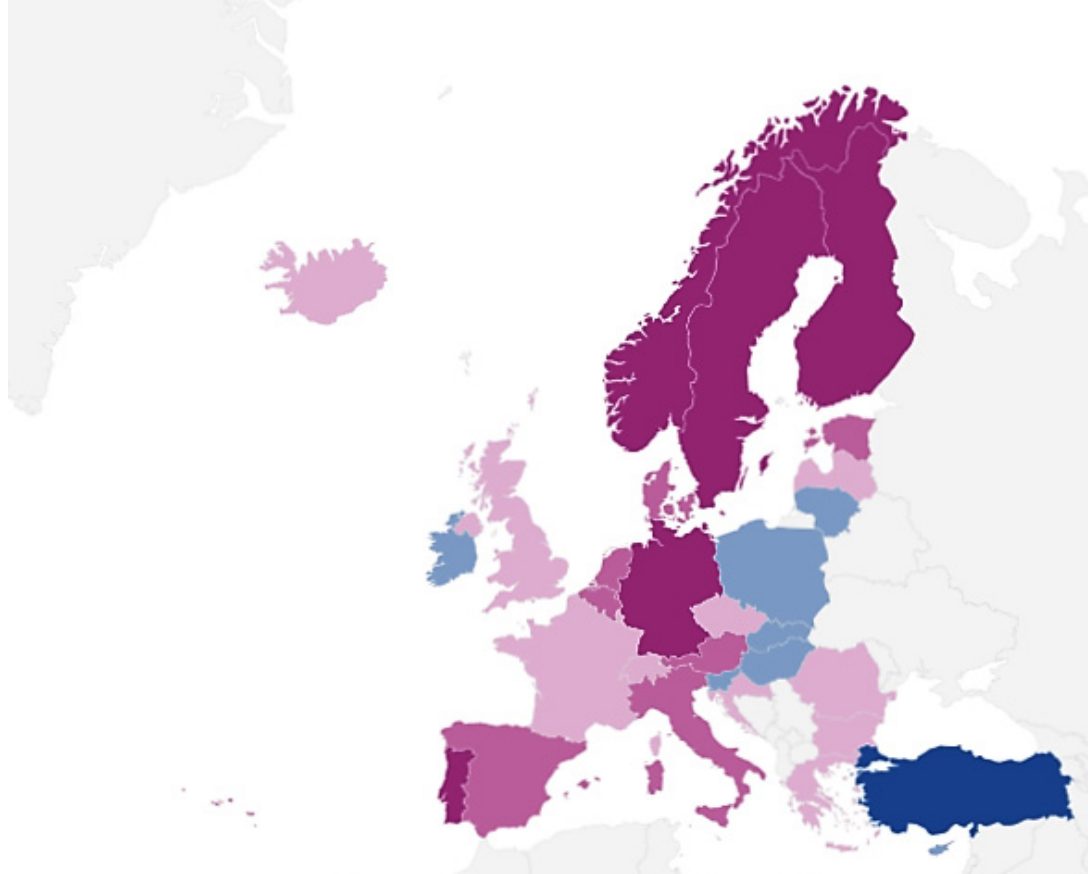

Source: MIPEX (http://www.mipex.eu/).

Notes: dark purple denotes favourable (80-100); purple: slightly favourable (60-79); light purple: favourable (4 1-59); light blue: slightly unfavourable (2 1-40); blue: unfavourable (0-20).

One of the key aspects in dealing with immigration is their integration into the local labour markets. Some countries realise that they need to design an attractive set of conditions that will attract the profile of immigrants that have the skills on demand in their local labour market. Facchini and Lodigiani (2014) have identified two predominant systems used in most advanced economies in the need of additional labour. Employer-driven schemes specify a set of minimum skill requirements as well as requiring that the migrant person acquire a job offer before being entitled for a work visa. Migrant-driven schemes rely on a predetermined set of desirable characteristics issued by policymakers that a migrant person has to meet. 
Croatia still does not have an elaborated strategy to deal with enlarged migration flows, nor their integration into its labour market.' There are certain actions, aimed at regulating migrant workers' inflow, through actions similar to employer-driven schemes. The Croatian government, in collaboration with the Croatian Employment Service and Employers' associations, defines quota requirements for working visas each year. This system indicates where the main demand for foreign workers lies. However, public discussions frequently argue that the quota system is not matched with the actual demand in the Croatian labour market and have called for the introduction of a systematic policy review.

Taking a comparative approach to the policy mix reveals that the highest policy score has been achieved for the segment of workers' rights where Croatia adopted EU legislation towards EU citizens and third-country persons (Figure 3). It should be noted that in that respect, the score for Croatia is even higher than that for the average EU-28 and certainly higher than Hungary and Slovenia. The story is similar with respect to indicators related to access to the labour market. Slovenia, on the other hand, scores relatively low when it comes to workers' rights and access to the labour market. It is also interesting to notice that Hungary has the lowest general support to immigrants.

The weakest link in all three countries is targeted support. This is a clear sign that prior to the outbreak of the migration crisis, the countries did not recognize the need to specifically deal with increased immigration flows. It seems that the policies in place ensure the same rights to the immigrant population as towards the natives, probably with the intention to avoid discrimination. However, they are not specifically oriented towards attracting and supporting additional immigration flows.

7 The latest strategic document covers the period 2013-2015, just before the outbreak of the migration flows through Croatian territory. It is more oriented towards the adoption of EU procedures than being actively orientated towards creating policies not prescribed by EU directives. Available at: http://www.mup.hr/UserDocsImages/minstarstvo/2013/ 
Figure 3. MIPEX scores for labour market, Croatia, Hungary, Slovenia and EU, 2014

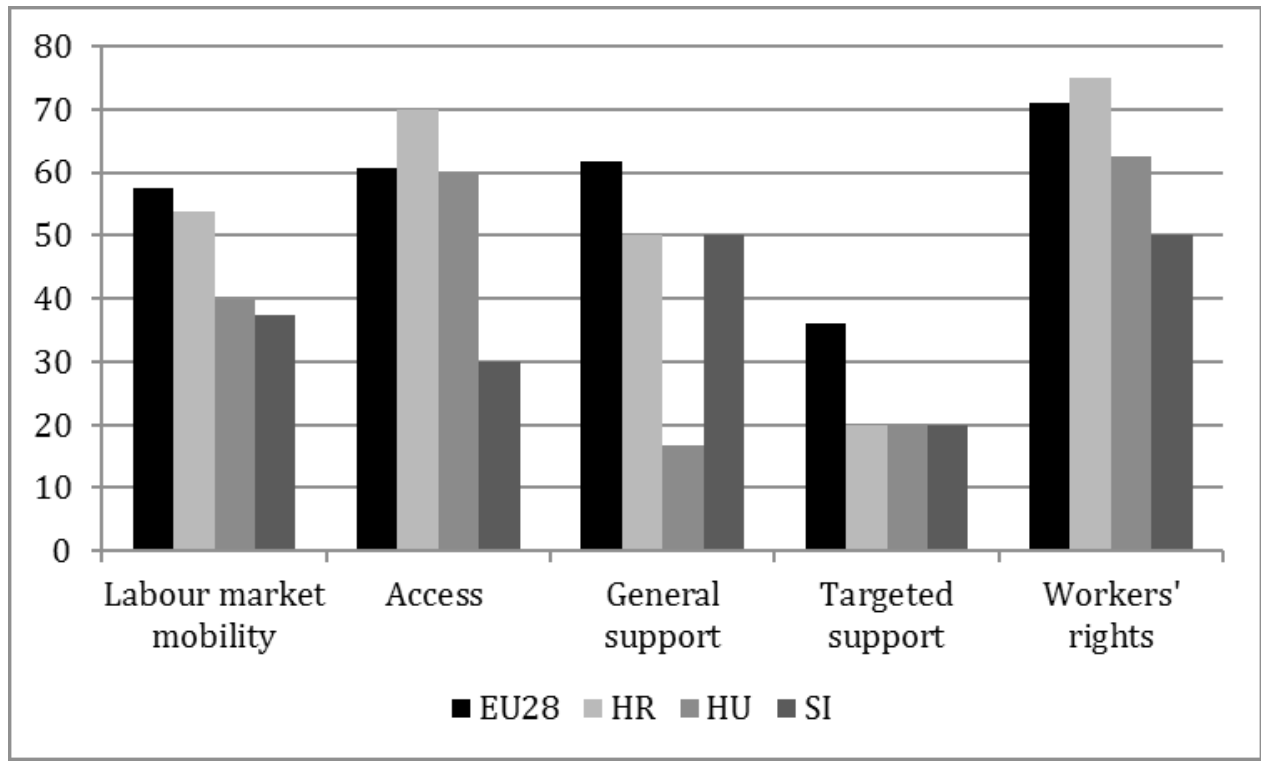

Source: MIPEX (http://www.mipex.eu/).

When considering the key policy challenges a country needs to address in order to improve the integration of immigrants into the local labour market, it is useful to consider the obstacles immigrants perceive to be important. Eurostat LFS $^{8}$ foresaw a lack of language skills, lack of recognition of qualifications, citizenship of residence permits, and origin, religion or social background as specific barriers deserving attention in the survey. The results for Croatia reveal that neither natives nor immigrants perceive precisely those as being important in their endeavours to find a suitable job. In all categories - employment, unemployment, and inactivity - approximately half (or more) of the respondents reported no barriers. The rest reported "other barriers", for which no additional information is provided. A similar picture is also found in the data for the employed and inactive foreign-born in Hungary (data are not disclosed for unemployed). However, in case of Slovenia, approximately 77 per cent of foreign-born employed and unemployed persons report experiencing "other barriers", while more than half of inactive persons report "no barriers".

However, the overall migration policy should be envisaged in a strategic sense, since human capital (domestic or imported) is a valuable resource. 
The recent evidence in Croatia implies a lack of an active stance; what is seen instead is a reaction towards what was perceived as an adverse economic and social situation. In the future, an active policy is desirable, not only in terms of complying with EU standards, but in terms of actively considering the use of available and potential human resources in the context of Croatian economic development.

\section{Labour market outcomes of immigrants}

In the context of economic activity, the most important question is active participation in the labour market. In this section we rely on the LFS data for the year 2014, recently provided (December 2015) by Eurostat. The survey is oriented towards the labour market outcomes of immigrants already living in their host countries. Since a specific migration module has been included in the LFS, this data source enables a discussion of some specific questions not usually included in the regular LFS survey. It also enables a comparative approach to all EU member states, since the survey relies on the same methodology.?

The literature frequently argues that immigrants, in particular those who have migrated due to humanitarian reasons, are less likely to participate in the local labour market. This is also sometimes a consequence of the host country's regulations, when asylum seekers are not allowed to participate in the labour market for a certain period of time (in order to distinguish them from economic migrants). To investigate this issue, we compared the activity rates of the native population with those of the foreign born, ${ }^{10}$ regardless of whether they had become residents or were still residents of other countries. ${ }^{11}$

9 The data used for comparative purposes in this paper are the data already aggregated for publication purposes by Eurostat. Bearing in mind that the methodology of the survey is already predefined, it was not possible to analyse other aspects not included in the survey. Since this is the first time that Croatia is included in the ad-hoc LFS module on migration, we are able to provide comparisons with other EU economies.

10 Throughout the paper we use the term "foreign-born" which refers to the first generation of immigrants. Eurostat data also enables an analysis of the first and second generation of immigrants. But this data is not always available for Croatia or the other analysed countries.

11 Eurostat enables a distinction between, for example, European Union residency and other countries. However, the data for Croatia is frequently not available or disclosed at this low levels of aggregation, probably due to statistical procedures disabling disclosure of data based on a relatively low number of survey responses. 
Table 2. Activity rates, employment and unemployment rates in 2014 , population 15-64

\begin{tabular}{|l|l|l|l|l|l|l|}
\hline \multirow{2}{*}{} & \multicolumn{3}{|l|}{ Croatia } & \multicolumn{2}{l|}{ Hungary } & \multicolumn{2}{l|}{ Slovenia } \\
\cline { 2 - 7 } & Native & $\begin{array}{l}\text { Foreign } \\
\text { born }\end{array}$ & Native & $\begin{array}{l}\text { Foreign } \\
\text { born }\end{array}$ & Native & $\begin{array}{l}\text { Foreign } \\
\text { born }\end{array}$ \\
\hline Activity rate & 65,5 & 66,5 & 66,6 & 73,0 & 71,6 & 68,4 \\
\hline Employment rate & 55,0 & 52,0 & 61,2 & 69,2 & 64,9 & 60,6 \\
\hline $\begin{array}{l}\text { Unemployment } \\
\text { rate }\end{array}$ & 16,1 & 21,9 & 8,2 & 5,2 & 9,3 & 11,4 \\
\hline
\end{tabular}

Source: Eurostat (http://ec.europa.eu/eurostat/data/database, Ifso_l4lactr, Ifso_l4lempr, Ifso_l4luner).

Among the analysed countries, Croatia exhibits the most unfavourable labour market indicators - the lowest activity and employment rate, the highest unemployment rate. Data for the year 2014 shows that the employment rate of the foreign-born aged 15-64 in Croatia was 52 per cent, which is lower than the native-born population of the same age group (55 per cent). In comparison to other European economies, the employment rate of foreign-born is at the bottom of the distribution, with similar rates recorded only in countries sharing similar labour market problems as Croatia - Greece (50.3) and Spain (52.3). At the top end of the distribution are Luxembourg (71.4), Czech Republic (70.7), and Lithuania (70.4).

Croatia is, due to its long lasting recession, a country in which it is relatively hard to find a job, as documented by high unemployment rates. The unemployment rate of the foreign-born aged 15-64 in Croatia was 21.9 per cent in 2014, while the comparable rate for the native-born population was 16.1 per cent. It is interesting to note that the unemployment rate of foreign-born in Hungary is lower than the unemployment rate of nativeborn. Thus, even though we have previously shown that the policy mix in Hungary is, in terms of the labour market, assessed as less favourable than in Croatia, the labour market outcomes of immigrants in Hungary seem to be more favourable.

Economic reasons might not be the only ones behind making the decision to migrate. The LFS ad-hoc module included a question concerning the main reasons for migrating, which included as alternatives: family reasons, 
education, work (job found before migrating), work (no job found before migrating), international protection or asylum, and other reasons. Those who have the highest employment rates of immigrants in Croatia came in order to pursue education (67.8 per cent). Those whose main reason was to find work ended up with an employment rate of 51 per cent if they had accepted a job prior to migrating and 53.1 per cent if they had not found a job before migrating, which is somewhat curious. Those who have sought international protection or asylum in Croatia have approximately the same employment rate (52.9 per cent) as those who came for family reasons (50.3 per cent).

The literature frequently argues that immigrants are adversely affected by the crisis (Hoynes et al. 2012), which might influence their decision to more readily accept a job offer for which they are over-qualified. Similarly, employers might not be familiar with the qualification systems in immigrants' home countries, so they might be more reluctant to hire immigrants for high-skilled jobs. This frequently has the consequence of immigrants accepting jobs for which they are over-qualified, and subsequently the skill upgrading of existing jobs, which leads to the altering of employers' perceptions regarding the skills required to perform certain tasks. In order to illustrate this issue, we resort to the self-declared over-qualification of employed persons (Table 3).

Table 3. Self-declared over-qualified employees as a percentage of the respective populations aged 15-64

\begin{tabular}{|l|l|l|}
\hline & Native-born & Foreign-born \\
\hline Belgium & 8,6 & 20,2 \\
\hline Czech Republic & 21,2 & 18,4 \\
\hline Estonia & 12,1 & 24,1 \\
\hline Greece & 13,1 & 13,4 \\
\hline Spain & 49,7 & 54,1 \\
\hline France & 17,0 & 28,7 \\
\hline Croatia & 10,9 & 16,4 \\
\hline Italy & 12,8 & 28,1 \\
\hline Cyprus & 40,1 & 38,2 \\
\hline Latvia & 18,9 & 14,5 \\
\hline Lithuania & 12,6 & 12,1 \\
\hline Luxembourg & 11,2 & 21,9 \\
\hline
\end{tabular}




\begin{tabular}{|l|l|l|}
\hline & Native-born & Foreign-born \\
\hline Hungary & $\mathbf{8 , 5}$ & $\mathbf{9 , 7}$ \\
\hline Malta & 19,0 & 25,4 \\
\hline Austria & 9,5 & 23,9 \\
\hline Poland & 19,8 & 20,8 \\
\hline Portugal & 27,1 & 33,3 \\
\hline Slovenia & 11,8 & 15,6 \\
\hline Slovakia & 42,6 & 32,3 \\
\hline Finland & 12,9 & 20,2 \\
\hline Sweden & 17,3 & 33,3 \\
\hline United Kingdom & 19,3 & 28,5 \\
\hline Norway & 12,6 & 22,3 \\
\hline Switzerland & 18,0 & 26,2 \\
\hline
\end{tabular}

Source: Eurostat (http://ec.europa.eu/eurostat/data/database, Ifso_14loq).

The comparative analysis for Croatia shows that employees declare themselves to be over-qualified for their job to a relatively smaller extent than in other countries. The share of people who report being overqualified is particularly high in Spain, Slovakia, and Cyprus. Furthermore, even though a larger share of the foreign-born population than natives believes that they are over-qualified, the difference is much larger in some other European countries (Italy, Austria, Belgium, Estonia, and Sweden). The data for Croatia might once again reflect the structure of immigrants, who mainly come from the neighbouring economies and the similarity of the qualification systems is partially also a consequence of the fact that not too long ago Croatia was a part of a wider economic and political union. Also, it is highly likely that young persons (possibly with dual citizenship) who come to Croatia for educational purposes chose to stay and work and are thus more readily recognized by employers. So, the relative similarity of foreign-born and natives when it comes to employment might not be sustained if the structure of immigrants, according to their nationality or race, significantly changes in the future.

We can augment the previous findings with the information on the methods the native and immigrant population uses to look for a job, which are presented in Table 4. 
Table 4. Methods used to find current job: Croatia, Hungary and Slovenia

\begin{tabular}{|l|l|l|l|l|l|l|}
\hline & \multicolumn{2}{|l|}{ Croatia } & \multicolumn{2}{l|}{ Hungary } & \multicolumn{2}{l|}{ Slovenia } \\
\cline { 2 - 7 } & Native & Immigrant & Native & Immigrant & Native & Immigrant \\
\hline $\begin{array}{l}\text { Contact public } \\
\text { employment office }\end{array}$ & 2,6 & & 4,9 & & 1,8 & 2,0 \\
\hline $\begin{array}{l}\text { Contact private } \\
\text { employment office }\end{array}$ & 0,6 & & 0,6 & & 0,8 & 2,8 \\
\hline $\begin{array}{l}\text { Person contacted } \\
\text { employer directly }\end{array}$ & 10,0 & 15,2 & 11,4 & 9,1 & 3,9 & 4,9 \\
\hline $\begin{array}{l}\text { Employer } \\
\text { contacted person } \\
\text { directly }\end{array}$ & 0,5 & 12,6 & 20,8 & 22,8 & 10,2 & 18,1 \\
\hline $\begin{array}{l}\text { Relatives, friends or } \\
\text { acquaintances }\end{array}$ & 9,1 & 1,3 & 1,0 & & 1,9 & \\
\hline $\begin{array}{l}\text { Education or } \\
\text { training institution }\end{array}$ & 11,5 & 7,8 & 8,6 & 11,5 & 10,9 & 7,3 \\
\hline $\begin{array}{l}\text { Study } \\
\text { advertisements }\end{array}$ & 0,8 & 1,0 & & 1,3 & 1,9 \\
\hline \begin{tabular}{l} 
Other method \\
\hline
\end{tabular} & & 1,8 & & & & \\
\hline
\end{tabular}

Source: Eurostat (http://ec.europa.eu/eurostat/data/database, Ifso_l4leecm).

The data shows that immigrants in Croatia are most likely to directly contact employer to find a job, followed by seeking information through friendship- and relative networks and advertisements. They do not seem to seek employment through institutions, but are rather more likely to establish direct contacts. In Slovenia and Hungary, relatives and acquaintances seem to also be an important source of information for job searches, but formal searches through advertisements are also popular.

It can be noted that in all three countries the public employment service was not listed as an important job search facility. The question is whether this situation is a consequence of an inadequate institutional setting or the preferences of the immigrants themselves. However, since policy instruments are usually channelled through public employment services, this issue deserves additional research in the future. 


\section{Conclusion}

The migration wave is not only at the doorstep, it is in full crest. The question is, consequently, not how to prepare for the upcoming events, but rather how to use the current circumstances to achieve the most beneficial outcome for all participants in the process. The key issue is to design policy measures that are able to match the skills of the migrant population to the versatile labour market needs in their destination countries. To design such policy instruments is certainly not an easy task. Policy measures are frequently influenced by public opinions, which are (partially) formed by the current state of social and economic affairs. The link between the three segments in the context of migration flows have been illustrated in this paper.

This paper has explored the relative position of foreign-born to natives in Croatia in comparison to neighbouring European economies. Attitudes towards immigrants, their labour market outcomes, and policies for their integration into the labour market were compared for Croatia, Hungary, and Slovenia. Three different data sources ensuring a comparable methodology have been used - the European Social Survey, Labour Force Survey, and MIPEX index - in order to indicate the relative position of the analysed countries. When comparing the labour market outcomes of foreign-born in Croatia to those in other European economies, Croatia does not stand out in any respect as being a country where the immigrant population is experiencing significantly worse (or better) conditions. Since Croatia lacks research on labour market integration of immigrants, this overview provides a useful indication of Croatia's position. It can also contribute to the discussion on how to shape the active migration policy in the future - a policy that will incorporate public opinion (to the extent that it affects the policy making in the country) but also has to reflect the local labour market conditions.

The analysis in the paper suggests that attitudes towards immigrants in Croatia have been relatively more favourable than in Slovenia and, in particular, Hungary. This has been translated into the more favourable assessment of the migration policies aimed at providing access to the labour market. However, the actual outcomes for immigrants in the Croatian labour market are the least favourable. The latter could be lat 
least partially) attributed to the fact that Croatia had the most pronounced negative effects of the latest economic crisis, and as a consequence the labour market indicators for the native population seem to be the worst in the Croatian case.

When considering the integration of immigrants into the local labour market from a policy perspective, it has to be emphasized that the recent migration concerns individuals who were not pre-selected by potential employers (as has been the case previously with the guest worker programmes the European countries favoured after the Second World War). They are also not arriving from neighbouring economies; thus they are relatively unfamiliar with the local economic conditions. Immigrants arrive for humanitarian reasons or as a result of the family reunification programme and carry specific skills and competencies which might or might not be in demand in the local labour market. In that respect they are not that different from persons seeking employment after completing education programmes ill suited for the current labour demand, an issue frequently discussed in many Croatian education policy debates. The question of matching the skills they have and the demand in the labour market is a delicate task, for which the institutions need to be prepared. Since the assessment of the policy measures indicated that targeted support is the weakest link in all three analysed countries, it could be argued that there is a need for substantial improvement in that area in order to increase the capacity of institutions in all three countries to deal with the current (and possibly future) increased migration flows. In that area, the assessment of the absorption capacities of the local labour markets is important for the success of the envisaged integration policies. Judging from the high structural unemployment currently present, at least in Croatia, further improvements in that respect should certainly be expected. 


\section{Bibliography}

Akrap, A., 2014. Promjene broja i prostornog razmještaja stanovništva Hrvatske i županija. In Puljiz, V., Tica, J. and Vidović, D., eds. Migracije i razvoj Hrvatske: Podloga za hrvatsku migracijsku strategiju, pp. 2571. Zagreb: HGK.

Borjas, G. J., 1987. Self-selection and the earnings of immigrants. American Economic Review, 77(4): 531-553.

Borjas, G. J., 2003. The labor demand curve is downward sloping: reexamining the impact of immigration on the labor market. The Quarterly Journal of Economics, 118(4): 1335-1374.

Botrić, V., 2015. Immigrants' characteristics and the Croatian labour market: an explorative study. Migracijske i etničke teme, 31 (1): 39-63.

Carmichael, R. and Woods, F., 2000. Ethnic penalties in unemployment and occupational attainment: evidence for Britain. International Review of Applied Economics, 14(1): 71-98.

Čačić-Kumpes, J., Gregurović, S. and Kumpes, J., 2012. Migracija, integracija i stavovi prema migrantima u Hrvatskoj. Revija za sociologiju, 42(3): 305-336.

Facchini, G. and Lodigiani, E., 2014. Attracting skilled immigrants: an overview of recent policy developments in advanced countries. National Institute Economic Review, 229: R3-R21.

Facchini, G. and Mayda, A. M., 2009. Does the welfare state affect individual attitudes towards immigrants? Evidence across countries. Review of Economics and Statistics, 91 (2): 295-314.

Franc, R., Šakić, V. and Kaliterna-Lipovčan, Lj., 2010. Percipirane posljedice doseljavanja i stav prema doseljavanju. Društvena istraživanja, 19(3): 421-440.

Gregurović, M., Kuti, S. and Župarić-llić, D., 2016. Attitudes towards immigrant workers and asylum seekers in eastern Croatia: dimensions, determinants and differences. Migracijske $i$ etničke teme, 32(1): 91-122. 
Hatton, T. J., 2015. Asylum policy in the EU: the case for deeper integration. CESifo Economic Studies, 61 (3): 605-637.

Heath, A. F., Rothon, C. and Kilpi, E., 2008. The second generation in western Europe: education, unemployment, and occupational attainment. Annual Review of Sociology, 34: 211-235.

Hoynes H., Miller D. L. and Schaller, J., 2012. Who suffers during recessions? Journal of Economic Perspectives, 26(3): 27-48.

Huskic, S., 2015. Fortress Europe and western Balkans as its soft underbelly. European Fund for the Balkans, paper series, September. Available at: http://balkanfund.org/fortress-europe/ [Accessed February 5 2016].

Huddleston, T., Bilgili, Ö., Joki, A.-L. and Vankova, Z., 2015. Migrant Integration Policy Index 2015. Barcelona/ Brussels: CIDOB and MPG. Available at: http://mipex.eu/sites/default/files/downloads/files/ mipex-2015-book-a5.pdf [Accessed May 25 2016].

Kahanec, M., Zaiceva, A. and Zimmermann, K. F., 2010. Ethnic Minorities in the European Union: An Overview. IZA Discussion Paper 5397. Bonn: IZA.

Kleven, H. J., Landais, C., Saez, E. and Schultz, E., 2014. Migration and wage effects of taxing top earners: evidence from foreigners' tax scheme in Denmark. The Quarterly Journal of Economics, 129(1): 333-378.

Krings, T., 2009. A race to the bottom? Trade unions, EU enlargement and the free movement of labour. European Journal of Industrial Relations, 15(1): 49-69.

Leamer, E. and Levinsohn, J., 1995. International trade theory: the evidence. In: Grossman G. and Rogoff, K., eds., Handbook of International Economics. vol. 3, pp 1339-1394. Amsterdam: NorthHolland.

Lewis, E., 2011 . Immigration, skill mix, and capital skill complementarity. The Quarterly Journal of Economics, 126(2): 1029-1069.

Lucassen, G. and Lubbers, M., 2012. Who fears what? Explaining far-rightwing preference in Europe by distinguishing perceived cultural and economic ethnic threats. Comparative Political Studies, 45(5): 547574. 
Marino, S., Penninx, R. and Roosblad, J. 2015. Trade unions, immigration and immigrants in Europe revisited: union's attitudes and actions under new conditions. Comparative Migration Studies, 3(1): 1-16. Available at: http://link.springer.com/article/10.1007/s40878-0150003-x/fulltext.html [Accessed September 29 2015].

Markaki Y. and Longhi S., 2013. What determines attitudes to immigration in European countries? An analysis at the regional level. Migration Studies, 1(3): 311-337.

Meardi, G., 2012. Union immobility? Trade unions and the freedoms of movement in the enlarged EU. British Journal of Industrial Relations, 50(1): 99-120.

Nejašmić, I. and Toskić, A., 2013. Starenje stanovništva U Hrvatskoj sadašnje stanje i perspective. Hrvatski geografski glasnik, 75(1): 89-110.

OECD/European Union. 2014. Matching Economic Migrations With Labour Market Needs. OECD Publishing. Available at: http://dx.doi. org/10.1787/9789264216501-en [Accessed July 20 2015].

Ortega, F. and Peri, G., 2013. The effect of income and immigration policies on international migration. Migration studies, 1 (1): 47-74.

Ottaviano, G.I.P. and Peri, G., 2012. Rethinking the effect of immigration on wages. Journal of the European Economic Association, 10(1): 152-197.

Reyneri, E. and Fullin, G., 2011 . Labour market penalties of new immigrants in new and old receiving west European countries. International Migration, 49(1): 31-57.

Richter, K. and Witkowski, B., 2014. Does growth generate jobs in Eastern Europe and Central Asia? The World Bank Policy Research Working Paper No. 6759. Available at: https://wbc-rti.info/object/ document/13844/attach/Does_Growth_generate_jobs_in_Eastern_ Europe_and_Central_Asia.pdf [Accessed November 20 2015].

Rustenbach, E., 2010. Sources of negative attitudes toward immigrants in Europe: a multi-level analysis. International Migration Review, 44(1): 53-77. 
Schieve, K. and Slaughter, M.J., 2001. Labor market competition and individual preferences over immigration policy. The Review of Economics and Statistics, 83(1): 133-145.

Smith, W. C. and Fernandez, F., 2015. Education and Wage Gaps: A Comparative Study of Immigrant and Native Employees in the United States and Canada. Available at: https://staticl. squarespace.com/static/51 bb74b8e4b0139570ddf020/t/54da78 4be4b026d7c8ca7e4e/1423603787112/Smith_Fernandez_PIAAC. pdf [Accessed January 15 2016].

Šram, Z., 2010. Ełnocentrizam, percepcija prijetnje i hrvatski nacionalni identitet. Migracijske i etničke teme, 26(2): 113-142.

Toshkov, D. and Kortenska, E., 2015. Does immigration undermine public support for integration in the European Union? JCMS: Journal of Common Market Studies, 53(4): 910-925.

Zaiceva, A., 2014. Post-Enlargement Emigration and New EU Members' Labour Markets. IZA World of Labor. Available at: http://wol.iza. org/articles/post-enlargement-emigration-and-new-EU-memberslabor-markets-1.pdf [Accessed October 17 2015].

Valerija Botrić (vbotric@eizg.hr) is a senior research associate employed by the Institute of Economics, Zagreb. She earned her PhD degree from the Faculty of Economics of the University of Zagreb in 2005. Labour markets in transition economies, with a special focus on Croatia, is one of the research areas in which she published a number of journal articles. She has also participated in projects focused on the analysis of labour market policies, evaluation of economic policies (in the segment of state aid), and the analysis of labour markets. In addition to labour markets, she has published articles in the area of macroeconomics, international economics and innovation. Recently, her research interests also include labour market aspects of migrations. 